DOI https://doi.org/10.18551/rjoas.2018-09.24

\title{
THE EFFECTS OF BRAND EQUITY ON FIRM VALUE AND PROFITABILITY IN INDONESIA
}

\author{
Wardianto K. Bagus* \\ Department of Business Administration, University of Lampung, Indonesia \\ Alhabsji Taher, Rahayu Sri Mangesti, Nuzula Nila Firdausi \\ Department of Business Administration, University of Brawijaya, Indonesia
}

*E-mail: kbagusw.unila@gmail.com

\begin{abstract}
The purpose of this study is to analyze the effect brand equity to firm value and profitability. Regression analysis in this research was done by using GSCA. The research sample in this research were enterprises in consumption sector listed in Indonesia Stock Exchanges 20122016 and meet the requirements of Hirose method of brand value calculation. As conclusion, brand equity is significantly affecting profitability, but insignificant to firm value.
\end{abstract}

\section{KEY WORDS}

Brand equity, profitability, firm value, business.

As the discussion of merger and acquisition of brand equity has grew popular, it has become an important concept in the study and practice of business. In around 1980, brand equity had become an intriguing topic and research study to business community (Huang, 2015; Hasan, Ullah \& Bhattacharjee, 2015). In the theory and practice of contemporary marketing (Davcik, 2013), brand equity was eventually be strategic business asset for a company. The most significant effect of brand equity is its ability to increase firm value (Lindemann, 2003: 29, Wang et al., 2015, as well as Arora and Chaudhary, 2016). The relation between brand equity and firm value is important as part of long-term strategy and company sustainable growth (Ukiwe, 2009).

A company with better brand equity will be easier to persuade costumer to use their products and services, resulting in the increase of profitability and firm value (Kotler and Keller, 2012: 242-243, as well as Lindemann, 2003: 28).

A research studying the effects of brand equity to the company financial condition is rare, especially in Indonesia. This research studying brand equity was performed to consumption sector listed in Indonesia Stock Exchange during 2012 - 2016 period. This research was analyzed with regression analysis GSCA. Therefore, this study aims to comprehend the effect of brand equity to a company financial performance measured by profitability and firm value.

\section{LITERATURE REVIEW}

Brand is the identity of a product used to distinguish products and services from competitors (Aaker, 1991; Hirose et al,. 2002). A brand is of the essence or the promise of a product sent to or experienced by the customers (Lee, 2012). Brand is a marketing asset stimulating present and future profit for the company (Keller, 1998).

Brand equity is identified as an ability of a brand to yield a future value, both its ability to have a premium price from consumer and attract investment, or facilitate the relation between interested parties (Arvidsson, 2006). Brand equity is also an additional value that the product achieves past investment of marketing activity of the brand (Keller, 2003).

Brand equity concept can be comprehended from four main perspectives namely investor (or brand owner), producer, reseller and consumer or customer (Ukiwe, 2009), in this case, the brand gives additional value to each respective party. Investors are also 
motivated by finance problem to take the brand and asset value from other companies (Cobb-Walgren, Ruble, \& Donthu, 1996). On the other hand, consumer and reseller are more motivated by the implication strategic brand equity (Keller, 1993). As for producer, the advantage of brand equity are the increase of product soles and better profit margin.

Brand equity serves a strong platform to producer to introduce new products and secure the brand from competitors. While reseller, brand equity gives contribution to their retail outlet and help product circulation in the outlet, sustains the availability of products and reduce the risk of having unsold products (Cobb-Walgren, Ruble, \& Donthu, 1996).

Developing and managing brand has been a priority for companies to maximize this asset value significantly (Lehmann et al., 2008). A company with a good branding has competitive advantages in the market, since a good branding is built from a good quality product or good supportive aspects such as different brand image and personality (Keller, 1998).

Companies with good brand equity will get market competitive advantages. This is also in line with RBV concept by Penrose (1959) and Wernerfelt (1984). Wernerfelt (1984) explains that based on RBV concept, a sustainable competitive advantage is derived from various resources optimization of a company. Good brand equity is also identified by a good reputation (Eng \& Keh, 2007). A high brand value or reputation is able to improve customers' perceived value (Hodović, Mehić and Arslanagić, 2011), yielding a higher stock price (Barney, 1986) as proxy for firm value.

The present of asymmetric information causes brand equity to be considered as a signal from the company, as in the signal theory, because the management comprehend the potential of the company more than investor does (Bhattacharyya, 1979). This signal is identified as "attribute or activity which gives information and can be manipulated" (Spence, 1994).

Brand signal comprised of strategy and mixed marketing from past and present experience related to branding, and incomplete asymmetric information serves as a credible market signal (Erdem and Swait, 1998). Signaling theory shows that a credible signal describes as to whether marketing signal is giving information effectively (Tirole, 1990). A company with credible brand is a signal of quality level for customer satisfaction, helping them to distinguish and choose products (Kotler and Keller, 2012: 242).

According to this assumption, good brand equity can be treated as a signal that the company is in a good condition. Company condition based on the signal of good brand equity is welcomed by the consumer and investor which will eventually increase firm value.

Good brand equity is proven empirically to significantly affect profitability (Ukiwe, 2009; Wang et al, 2015; as well as Arora and Chaundhary, 2016). Good brand equity is proven empirically to significantly affect firm value (Wang et al., 2015, as well as Arora and Chaudhary, 2016). While the research by Ukiwe (2009) shows the opposite effect that brand equity insignificantly affects firm value.

Based on this review, this research studies the effect of brand equity to profitability and firm value in consumption sector in Indonesia.

\section{METHODS OF RESEARCH}

Brand equity in this research was treated as exogenous variable. Brand equity in this research was measured by brand value. Brand value served as a proxy for the reputation and the goodwill of the company (Eng \& Keh, 2007). Brand value, as in Hirose theory, et al. (2002), was a conception of competitive advantages via branding to increase present and future profit by utilizing competitive price, high customer loyalty and the power of brand expansion. Hirose, et al. (2002) assumed that brand value served as a proxy of three main factors, namely:

$$
B V=f(P D, L D, E D, r)=\frac{P D}{r}+L D+E D
$$

Source: Hirose, et al. (2002) 
Where: $\mathrm{BV}=$ brand value; $\mathrm{PD}=$ prestige driver; $\mathrm{LD}=$ loyalty drive; $\mathrm{ED}=$ extension driver; $r=$ risk-free interest (discount) rate.

PD was a cash flow arose from price profit or brand value. PD was calculated in more detail by the following formula:

$$
P D=\frac{1}{5} \sum_{i=-4}^{0}\left\{\left[\frac{S_{i}}{C_{i}}-\frac{S^{*} i}{C^{*} i}\right] * \frac{A D_{i}}{O_{i}}\right\} * C_{0}
$$

Source: Hirose, et al. (2002)

Where: $S=$ sales of firms; $P D=$ prestige driver; $C=$ cost of sales of firms; $S^{*}=$ sales of a benchmark company; $C^{*}=$ cost of sales a benchmark company; $A D=$ advertising expense and promotion cost; $O E=$ total operation expenses.

Benchmark Company, in this formula, was a company treated as a standard comparison to assess brand equity. The sales rate of Benchmark Company was defined in two ways namely average sales and the lowest sales of competitors (Hirose et al., 2002).

LD referred to the ability of a brand to sustain long-term sales in stable condition as the consequence of customer loyalty to buy the same product with the same brand. LD was the cost of sales stability. LD was calculated with the following formula:

$$
L D=\frac{\mu c-\sigma c}{\mu c}
$$

Source: Hirose, et al. (2002)

Where: $\mathrm{LD}=$ loyalty driver; $\mu_{\mathrm{c}}=$ five-year average of firms' cost of sales; $\sigma_{c}=$ five-year standard deviation of firms' cost of sales.

ED determined the brand expansion, which reflects the ability of well-known brand to expand their business network to all different industries in different region. In order to quantify ED the following formula was used:

$$
E D=\frac{1}{2} \sum_{i=-1}^{0}\left\lfloor\frac{S X_{i}-S X_{i-1}}{S X_{i-1}}+1\right\rfloor
$$

Source: Hirose, et al. (2002)

Where: $\mathrm{ED}=$ extension driver; $S X=$ sales from non-core and oversea business.

Endogenous variable in this research was profitability and firm value. Profitability was measured with return on assets (ROA) and return on equity (ROE). Firm value is measured with market to book ratio (MBR) and Tobin's $Q$.

\section{RESULTS AND DISCUSSION}

This research investigated the effect of brand equity to profitability and firm value in consumption sector in Indonesia. The sample of this research were companies in consumption sector in Indonesia fulfilling certain requirements such as frequently publish their finance report during 2012 to 2016 period and their brand value could be calculated by using Hirose method. Based on these criteria, 22 companies were chosen as research sample. There were total of 110 analysis units (22 companies in 5 years). Regression analysis in this research was done by using GSCA software.

Based on table 1, FIT value is 0.364 which means that brand equity, profitability and firm value can be explained in this model by $36.4 \%$, while the other $63.6 \%$ were explained by another variables outside the scope of this research. While AFIT value is 0.355 which means 
that brand equity, profitability and firm value can be explained in this model by $35.5 \%$, while the other $64.5 \%$ were explained by another variable outside the scope of this research.

Table 1 - Goodness of Fit

\begin{tabular}{|c|c|}
\hline \multicolumn{2}{|c|}{ Model Fit } \\
\hline FIT & 0.364 \\
\hline AFIT & 0.355 \\
\hline NPAR & 10 \\
\hline
\end{tabular}

The result of table 2 indicates that brand equity has 3 indicators. From weight estimation value from each indicator, prestige driver (PD) is the best indicator to describe brand equity. This is because the estimation value of PD is the biggest among the 3 , which is 1.019. According to acquired critical point, PD gives dominant and significant effect to brand equity since the acquired critical point value is $21.91^{*}$ significant at $95 \%$ confidence level.

Profitability variable has 2 indicators. From loading estimation value from each indicator, return on equity (ROE) is the best indicator to describe Profitability. This is because the estimation value of ROE is bigger than return on assets (ROA) which is 1.472 . According to acquired critical point, ROA gives significant effect to profitability since the acquired critical point value is $14.19^{*}$ significant at $95 \%$ confidence level.

While firm value variable has 2 indicators. From weight estimation value from each indicator, market to book ratio (MBR) is the best indicator to describe firm value. This is because the estimation value of MBR is bigger than Tobin's $Q$ which is 1.403 . According to acquired critical point, MBR gives significant effect to firm value since the acquired critical point value is $9.72^{*}$ significant at $95 \%$ confidence level.

Table 2 - Measurement Model

\begin{tabular}{|c|c|c|c|c|c|c|c|c|c|}
\hline Variable & \multicolumn{3}{|c|}{ Loading } & \multicolumn{3}{c|}{ Weight } & \multicolumn{3}{c|}{ SMC } \\
\hline & Estimate & SE & CR & Estimate & SE & CR & Estimate & SE & CR \\
\hline \hline LV_1 & \multicolumn{8}{|c|}{ AVE $=0.000$, Alpha =-0.075 } \\
\hline LnPD & 0 & 0 & 0 & 1.019 & 0.046 & $21.91^{*}$ & 0 & 0 & 0 \\
\hline LD & 0 & 0 & 0 & -0.203 & 0.157 & 1.29 & 0 & 0 & 0 \\
\hline ED & 0 & 0 & 0 & -0.129 & 0.179 & 0.72 & 0 & 0 & 0 \\
\hline \hline LV_2 & \multicolumn{8}{|c|}{ AVE $=0.000$, Alpha $=0.731$} \\
\hline ROA & 0 & 0 & 0 & -0.625 & 0.155 & $4.02^{*}$ & 0 & 0 & 0 \\
\hline ROE & 0 & 0 & 0 & 1.472 & 0.104 & $14.19^{*}$ & 0 & 0 & 0 \\
\hline \hline LV_3 & 0 & 0 & 0 & 1.403 & 0.144 & $9.72^{*}$ & 0 & 0 & 0 \\
\hline MBR & 0 & 0 & 0 & -0.442 & 0.166 & $2.66^{*}$ & 0 & 0 & 0 \\
\hline TQ & 0 &
\end{tabular}

$C R^{*}=$ significant at .05 level.

Brand equity has a positive relation and significant to profitability since acquired critical value is significant in $95 \%$ confident level and consequently brand equity affects profitability. This result is in line with Ukiwe (2009), Wang, et al. (2015), as well as Arora and Chaudhary (2016) wherein profitability is measured with EPS. However, the result is different with Arora and Chaudhary (2016) if profitability is measured by RAE and ROE, wherein brand equity has negative relation and significant to capital structure.

Brand equity has an insignificant relation to firm value since acquired critical value is significant in $95 \%$ confident level and consequently brand equity affects firm value. This result is in line with Ukiwe (2009) wherein brand equity is insignificant to firm value. This result is different with Wang, et al. (2015), Arora and Chaudhary (2016).

Profitability has a positive relation and significant to firm value since acquired critical value is significant in $95 \%$ confident level and consequently profitability affects firm value. This result is also align with Yu (2015), Siboni and Pourali (2015), Ansar, Butt and Shah 
(2015), Akit, Hamzah and Ahmad (2015), Majanga (2015). This result is different with Sharif, Ali and Jan (2015), Al Masum (2014) wherein profitability has a negative relation and significant to firm value.

Table 3 - Structural Model

\begin{tabular}{|c|c|c|c|}
\hline \multicolumn{4}{|c|}{ Path Coefficients } \\
\hline $\mathrm{n} / \mathrm{n}$ & Estimate & $\mathrm{SE}$ & $\mathrm{CR}$ \\
\hline Brand Equity -> Profitability & 0.383 & 0.080 & $4.81^{*}$ \\
\hline Brand Equity -> Firm Value & 0.057 & 0.033 & 1.73 \\
\hline Profitability -> Firm Value & 0.949 & 0.017 & $56.68^{*}$ \\
\hline
\end{tabular}

$C R^{*}=$ significant at .05 level.

Based on this research result, it is known that high brand equity is able to assure consumer of the product quality they bought. This can sustain the sales stability and eventually increase profitability. However, average brand equity is not interesting enough for stockholder or investor who are more interested in a high profitability. A high profitability causes cash flow to progress towards the owner and the operating result of the company will increase. The increment of cash flow will eventually increase the firm value.

\section{CONCLUSION}

A research correlating brand equity with profitability and firm value is infrequent, especially in Indonesia. Hence, this research aspires to study the consistency of the effect of brand value to financial performance, specifically in Indonesia.

The research result indicates that brand equity significantly affects profitability. This significant relation between brand equity and profitability supports RBV concept and signaling theory.

The future research should understand the relation between brand equity with financial policy such as capital structure and investment. It is also suggested to study the effect of capital structure and profitability to brand equity, since there is a probability that brand equity is also affected by capital structure and profitability. Lastly, similar researches should be performed in another industry to fully comprehend the implementation of brand equity in Indonesia.

\section{REFERENCES}

1. Aaker, D. A. (1991). "Managing brand equity: Capitalizing on the Value of a Brand Name." New York: Free Press.

2. Ahmad, K., S.Z.A. Shah, H. Bilal and H. Ahmad. (2013). "Impact of Financial Leverage on Firm Investment." African Journal of Business Management. Inj. 7 (14): 1115-1125

3. Akit, F.M., N.H. Hamzah and N. Ahmad. (2015). "Impact of Dividend Policy on the Shareholders' Wealth: Shariah vs Non -Shariah Companies." Full Paper Proceeding GTAR-2015, Vol. 2, 722-743.

4. Al Masum, A. (2014). "Dividend Policy and Its Impact on Stock Price - A Study on Commercial Banks Listed in Dhaka Stock Exchange." Global Disclosure of Economics and Business, Volume 3, No 1.

5. Arora, S. and N. Chaudhary. (2016). "Impact of Brand Value on Financial Performance of Banks: An Empirical Study on Indian Banks." Universal Journal of Industrial and Business Management. 4(3): 88-96.

6. Arvidsson, A. (2006). "Brand value." Journal of Brand Management. 13(3): 188-192

7. Barney, J. (1986). "Organizational Culture: Can it be a Source Sustainable Competitive Advantage?" Academy of Management Review. 11: 656-665

8. Ansar, I., A.A. Butt and S.B.H. Shah. (2015). "Impact of Dividend Policy on Shareholder's Wealth." International Review of Management and Business Research, Vol. 4(1). 
9. Bhattacharya, N. (1979). "Imperfect Information, Dividend Policy, and the Bird in the Hand Fallacy." The Bell Journal of Economics, Vol. 10. No. 1, pp. 259-270

10. Davcik, Nebojsa St. (2013). "An empirical investigation of brand equity: drivers and their consequences." British Food Journal, 115 No. 9: 1342-1360

11. Eng, L. L., and H. T. Keh. (2007). "The Effects of Advertising and Brand Value on Future Operating and Market Performance." Journal of Advertising.36: 91-100

12. Hasan, M., K.T. Ullah and H. Bhattacharjee. (2015). "Brand Valuation of Commercial Banks in Bangladesh: An Application of Marketing Profitability." Journal of Business Theory and Practice. 3, No. 2.

13. Hirose, Y. (2002). The Report of the Committee on Brand Valuation. The Ministry of Economy, Trade and Industry of the Government of Japan.

14. Hodović, V.B., E. Mehić and M. Arslanagić. (2011). "Influence of Banks' Corporate Reputation on Organizational Buyers Perceived Value." Procedia Social and Behavioral Sciences 24:351-360.

15. Huang, J. (2015). "A Review of Brand Valuation Method." Journal of Service Science and Management, 2015, 8, 71-76.

16. Keller, K. L. (1998). "Strategic Brand Management: Building, Measuring and Managing Brand Equity." New Jersey: Prentice Hall.

17. Keller, K. L. (2003). "Strategic Brand Management: Building, Measuring, and Managing Brand Equity, $2^{\text {nd }}$ ed." Upper Saddle River, NJ: Prentice-Hall.

18. Khan, M.N., B. Nadeem, F. Islam, M. Salman, and H. M. I. S. Gill. (2016). "Impact of Dividend Policy on Firm Performance: An Empirical Evidence From Pakistan Stock Exchange." American Journal of Economics, Finance and Management. ISSN: 23816864 (Print); ISSN: 2381-6902 (Online). 2, No. 4, pp. 28-34

19. Kotler, P. and K. L. Keller. (2012). Marketing Management. 14th ed. Pearson Education, Inc., publishing as Prentice Hall, One Lake Street, Upper Saddle River, New Jersey 07458.

20. Erdem, T. and J. Swait. (1998). Brand Equity as a Signaling Phenomenon. Journal of Consumer Psychology. 7(2). 131-157

21. Lee, H. (2012). "Brand Valuation Model: A Shareholder Value Approach." Disertasi. Kent State University.

22. Lehmann, R. D., K. L. Keller, and J. U. Farley. (2008). "The structure of survey-based brand metrics." Journal of International Marketing, 16(4), 29-56.

23. Lindemann, Jan. 2003. Brand Valuation. In R. Clifton and J. Simmons (ed) Brands and Branding, Published by Profile Books Ltd. London.

24. Majanga, Byson B. (2015). "The Dividend Effect on Stock Price-An Empirical Analysis of Malawi Listed Companies." Accounting and Finance Research. Inj. 4, No. 3; 2015.

25. Myers S.C. and Majluf N. (1984). Corporate financing and investment decisions when firms have information that investors do not have, Journal of Financial Economics, 13, 187-221.

26. Penrose, E. T. (1959). The Theory of the Growth of the Firm. New York: John Wiley.

27. Sajid, M., A. Mahmood and H. M. Sabir. (2016). "Does Financial Leverage Influence Investment Decisions? Empirical Evidence From KSE-30 Index of Pakistan." Asian Journal of Economic Modelling, 2016, 4(2): 82-89

28. Sharif, I., A. Ali and F. A. Jan. (2015). "Effect of Dividend Policy on Stock Prices." Journal of Management Info 6(1), 55-85.

29. Siboni, Z. M. and M. R. Pourali. (2015). "The Relationship between Investment Opportunity, Dividend Policy and Firm Value in Companies Listed in TSE: Evidence from IRAN." European Online Journal of Natural and Social Sciences 2015; Vol.4, No.1 Special Issue on New Dimensions in Economics, Accounting and Management. ISSN 1805-3602.

30. Spence, A. M. (1994). Market Signalling. Cambridge MA-Harvard University Press. 31. Tirole, J. (1990). The Theory of Industrial Organization. Cambridge, MA MIT Press. 
32. Ukiwe, Alladin O. (2009). "The Joint Impact of Brand Value and Advertising on Corporate Financial Performance and on Stock Return: A Case study of the Computer Industry." Unpublished Dissertation. Walden University.

33. Vithessonthi, C. and Olimpia C. Racela. (2016). "Short- and long-run effects of internationalization and R\&D intensity on firm performance." Journal of Multinational Financial Management. 34: 28-45.

34. Wang, D. H.-M., P.-H. Chen, T. H.-K. Yu and C.-Y. Hsiao. (2015). "The effects of corporate social responsibility on brand equity and firm performance." Journal of Business Research. 68: 2232-2236

35. Wernerfelt, B. (1984). "A Resource-Based View of the Firm." Strategic Management Journal. Inj. 5 No. 2: 171-180.

36. Yu, C.-P. (2015). "Financial policies on firm performance: The U.S. insurance industry before and after the global financial crisis." Economic Modelling. 51: 391-402. 